\title{
Angles
}

New Perspectives on the Anglophone World

$9 \mid 2019$

Reinventing the Sea

\section{The Shipwrecked Slaves of Tromelin Island: A Crime of Lese-Humanity}

Joëlle Weeks

\section{(2) OpenEdition}

1 Journals

Electronic version

URL: https://journals.openedition.org/angles/820

DOI: 10.4000/angles.820

ISSN: 2274-2042

\section{Publisher}

Société des Anglicistes de l'Enseignement Supérieur

\section{Electronic reference}

Joëlle Weeks, "The Shipwrecked Slaves of Tromelin Island: A Crime of Lese-Humanity", Angles [Online], 9 | 2019, Online since 01 November 2019, connection on 06 June 2022. URL: http:// journals.openedition.org/angles/820 ; DOI: https://doi.org/10.4000/angles.820

This text was automatically generated on 6 June 2022.

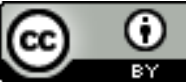

Angles est mise à disposition selon les termes de la Licence Creative Commons Attribution 4.0 International. 


\title{
The Shipwrecked Slaves of Tromelin Island: A Crime of Lese-Humanity
}

\author{
Joëlle Weeks
}

1 Tromelin Island, a tiny speck in the Indian Ocean, was the stage of a tragedy which became a cause célèbre in France and led to the short-lived abolition of slavery during the French Revolution. "A crime of lese-humanity" was the condemnatory expression used by Condorcet in his 1781 pamphlet "Reflections on Negro Slavery" which included the tale of the 1761 shipwreck of The Utile, 450 kilometres from Madagascar. It led to the stranding on what was then called the Isle de Sable (Sand Island) of $123 \mathrm{crew}$ and over 80 slaves (half of the slave men, women and children who had initially boarded the ship were drowned in the shipwreck). While the 123 seamen sailed back to civilisation, the fourscore surviving slaves embarked in Madagascar had to wait for 15 years before being rescued. Only seven women survived the ordeal, along with a baby boy - all the other men, women and children had died. 
Figure 1. Map of Tromelin Island (in French: île de Sable), Paris, Archives Nationales, 1761

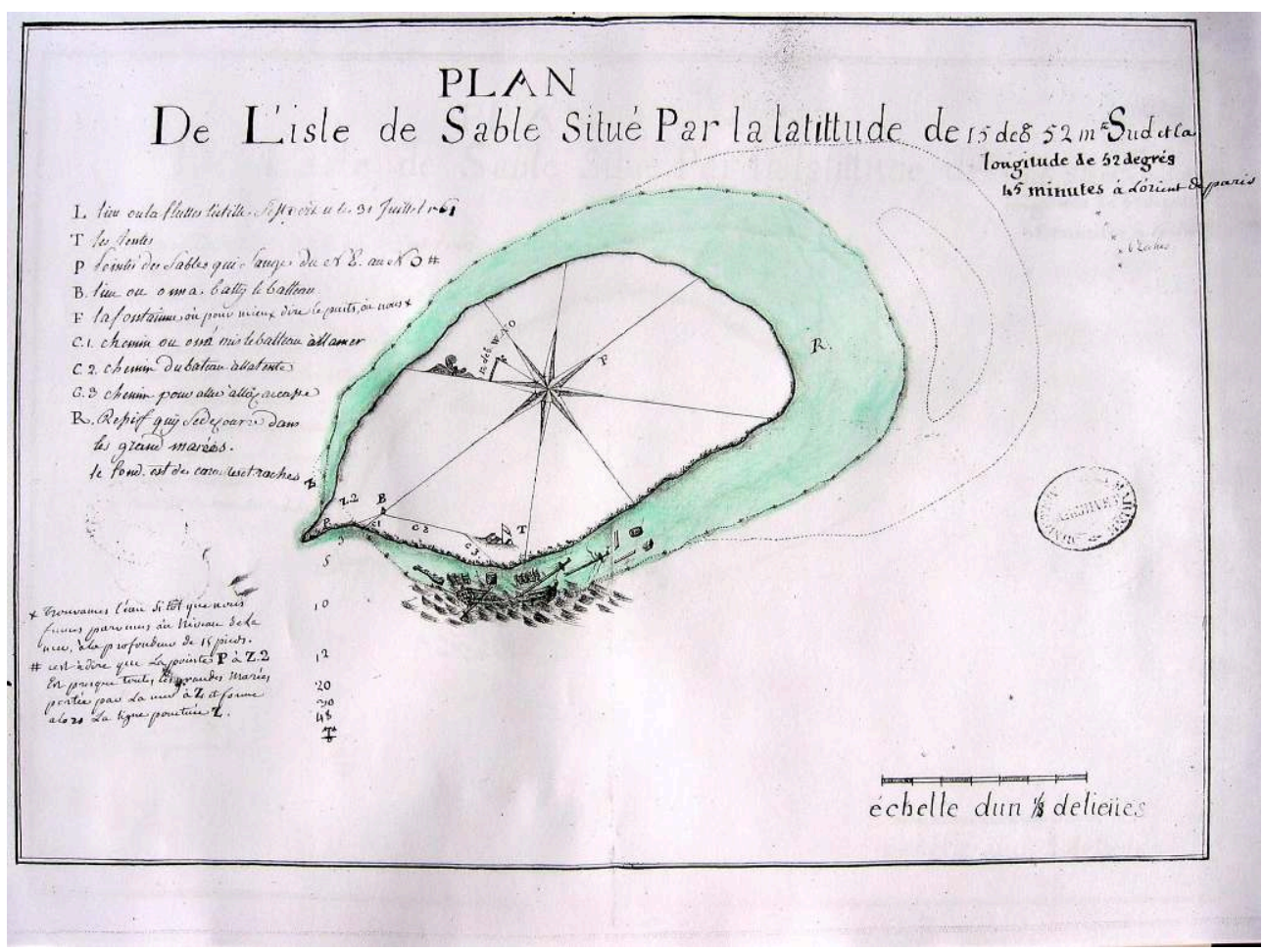

Source: http://m.musee-aquitaine-bordeaux.fr/fr/evenement/conference-tromelin-bilan-10-ans-derecherches

This Robinson-Crusoesque tragedy encapsulates many of the geopolitical issues of the closing $18^{\text {th }}$ century: the rivalry between the French and the English during the Seven Years' War for dominance in India and control of the sea route across the Indian Ocean.

The economic role of the ports of call in the Indian Ocean was crucial as a source of food and water. A budding plantation economy emerged in the wake of the need for ships' crews to obtain fresh supplies and nurse their sick. Western ideology was reflected in the predatory relation to the natives, with the practice of slavery and the drastic exploitation of natural resources which exemplified environmental awareness and greed.

Utopian dreams and schemes were enacted on these tiny islands, either picked randomly or as stopovers, refuge and safe havens for castaways after shipwrecks. They could be selected as spaces where societies would be born anew for modern pilgrims and outcasts. A large body of literature emerged on those topics both in France and Britain foregrounding the revolutionary ideas and upheavals of 1789 in France. This contribution will attempt to cast light on all of these aspects in the hope of paying tribute to the marooned slaves of Tromelin Island.

\section{Geopolitics: Anglo-French Rivalry}

By the end of the $18^{\text {th }}$ century, the British had asserted their supremacy in India after the battle of Plassey in 1757 which led to the annexation of Bengal; the Dutch concentrated their activities on Indonesia and the Spice Islands and the Portuguese kept a few factories in India but focused rather on South America. The French also 
retained a measure of power in their factories on the Eastern coast of India, but the British were in a better position as a result of their commercial superiority due in part to the private ownership of the East India Company and the support of the British government. After Dupleix's impeachment in 1754 and death in 1763, the French lost their clout and advantage and the backing of the king. Nevertheless, trade with India and South East Asia was on the rise and all countries needed to ensure access to, and control of, various ports of call in the Atlantic and Indian Ocean, namely, Ile de France and Bourbon Island, colonised to ensure safe passage to India. Those ports ranged from outposts and basic havens to trading posts, settlements or factories. Most had been disputed territories like Cape Verde, Madeira, Ascension, Saint Helena, and the Cape. The Macarena Islands, Bourbon (Reunion) and Ile de France (Mauritius) had been successively Portuguese, Dutch, French and British.

\section{Logistics}

Logistics were also crucial: navigation constraints dictated by winds, currents, the layout of ports, access of leeward bays, problems of calculating latitude and longitude, and last but not least, health problems resulting from the lack of fresh food, source of scorbutic illnesses which decimated crews. Contrary to popular belief, these islands were not virgin territories - previous countries, navigators and traders had left their imprint. Very few territories did not feature on maps and charts and some were the source of heated dispute among navigators and scientists. This was the case of Sand Island, renamed Tromelin Island after the rescue of the marooned slaves. Its coordinates were calculated as late as 1954 , along with other scattered islands identified by d'Après de Mannevillette whose aim was to amend the standard Company map of Bayonne. ${ }^{1}$

\section{Economics of the Passage to India}

7 Though essential transactions were carried on in India, American bullion was needed for textiles in India and spices in Indonesia. Those ports of calls were essential for supplies of fresh food and water. Over time, those ports became settlements which would be peopled and exploited. A plantation economy was created, the primary products being cloves, coffee, and sugar besides spices and plants a clever botanist had stowed away from Indonesia. Pierre Poivre, the aptly named French botanist, had indeed stolen seeds from Dutch colonies in Indonesia and managed to grow nutmeg, pepper, and clove in Mauritius. These new plantations required more labour force. The darker side of this logistics emerged in the mid 1750s as human trafficking, although illegal in France, had become the new trade in the colonies. Bourbon Island (Reunion) and Ile de France (Mauritius) launched their particular plantation systems for cloves, coffee and sugar in the Mascarene Islands.

As we shall see, a brighter aspect of this evolution was the birth of the green economy: conscious of the need to protect and nurse nature essentially to fend off drought, settlers engaged in extensive and successful tree plantation programmes (Grove 1995). The realisation that resources were limited became obvious and there was food shortage on Mauritius as early as 1735. Land management and conservation policy response in Saint Helena was due to the strategic value of the island. The downside of 
these discoveries was the extinction of entire species such as turtles on Rodrigues Island and the dodo on Mauritius and other tropical areas dominated by European trading companies (Portuguese, Dutch, British, and French).

\section{Utopian Dreams \& Schemes}

9 Those islands could be construed as a refuge for exiles and dissenters. As early as 1691, Protestants fled Catholic France to settle on Rodrigues Island ${ }^{2}$ which stood as a new Eden for dissenters. Yet the slave Crusoes of Tromelin Island, as they were later called, marooned on a barren island, had no choice but to reconstruct a social structure which would enable them to survive. Their resourcefulness and ingenuity were a mirror image of what had happened fifteen years earlier when some of the crew and slaves managed to build a raft. Yet the slaves were ultimately prevented from sailing away with the crew: class and race meant they were not worthy of such a fate.

\section{Western Ideology. From an "Environmental Gospel" to Humanitarian Concerns and Reformism}

10 The European ideology of the late $18^{\text {th }}$ century was reflected in the predatory nature of the relation between Europeans, the new environments and native populations (in the case of Tromelin Island, with the marooned slaves). Paradoxically, this relation also was at the root of environmentalism and humanitarian concerns.

11 European expansion along sea routes, triggered by nascent capitalism and operated by charter trading companies, confronted traders, travellers, seamen, scientists with a radically different natural world. While journeying was a collective intellectual experience, it involved producing personal accounts which often added minor details to the wealth of material gathered by earlier travellers. It was also religious in nature.

12 From the $17^{\text {th }}$ century onwards the physio-naturalists dictated their imperative to the scientists and the educated which implied reading the divine design in the universe. Understanding and making sense of the patterns in the Creation was the duty of the learned and an acknowledgement of God's power.

13 This intellectual grasp entailed moral responsibility; while this divine design set man firmly at the centre of creation, it implied rigorous stewardship and responsible husbandry. The same religious sensibilities and intellectual framework inspired Calvinist Holland in re-evaluating the natural world as a path to God. After 1770, Scottish protestant doctors and missionary travellers set out to preach an environmental gospel (Grove 1995).

14 Both philosophical and religious responses to the encounter with the tropical world were dictated by observations of tropical islands. Islands were a central motif in a new discourse about nature which reflected environmentalist and conservationist approaches. In his ground-breaking study, Green Imperialism: Colonial Expansion, Tropical Island Edens and the Origins of Environmentalism, 1600-1860, Richard Grove points to two concepts, the island and the botanical garden, as metaphors defining man's relationship to nature but also, and more to the point, as microcosms and laboratories where environmental crises were played out, tensions resolved and agendas set up and implemented (Grove 1995). 

was tied up in the expansion of slavery. Slave labour was gradually beginning to replace indentured servitude in the Caribbean as sugar edged out tobacco production. During the 1700s, French planters established sugar, coffee, and indigo plantations off the east coast of Africa, modelled after those in the Americas, and the demand for workers seemed inexhaustible (Peabody 1994). ${ }^{3}$ As sugar emerged as the major cash crop, this meant more slaves were needed. Most of the slaves were imported from Portuguese Mozambique and Madagascar. The slave population in the Mascarene Islands rose from 33,000 in 1765 to more than 93,000 in the 1790s (Campbell 2004: 35).

21 Slavery was illegal in France itself. Since the $16^{\text {th }}$ century, French courts recognised that a person became free once he or she set foot on French soil, which became the basis of the French "free soil" principle. In 1765, Louis de Jaucourt, who contributed to Diderot's Encyclopédie, stated that slavery as a system

violates religion, morality, natural law, and all human rights. There is not one of those unfortunate souls who does not have the right to be declared free, since in truth he has never lost his freedom; and he could not lose it, since it was impossible 
for him to lose it; and neither his prince, his father, nor anyone else had the right to

dispose of it. (Jaucourt qtd. in Thomas 1997: 466)

The Parliament of Paris, France's highest court, refused to register two of the king's laws allowing even a conditional slavery to exist within the country. The most cited articulation of France's "free soil" principle was "France, mother of liberty, allows no slaves," as the Parliament of Guyenne reportedly ruled after a Norman merchant attempted to sell several Moors he had purchased on the Barbary Coast. And before the French Empire's expansion into the Caribbean and sub-Saharan Africa, the archetypal French slave was either a Muslim abducted to Europe or a Christian abducted to North Africa (Weiss 2011).

This trade remained the monopoly of the Company until the 1740, but this traffic became more and more the prerogative of the Company's servants. The slave trade increased with the 1769 Royal Decree opening the Mascarene Islands to free trade by all French nationals.

\section{Utopia or Dystopia}

24 The mindset of $18^{\text {th }}$-century traders, seamen, and officials from trading companies was illustrated in the telling tragedy of 1761 which was the shipwreck and ordeal of the French crew from the Utile and its cargo of slaves on Tromelin Island. The episode epitomised the geopolitics of the period, the science, the economics, the ideology and ethics prevailing during the closing $18^{\text {th }}$ century.

The political context, the Seven Years' War between the French and the English, drove various protagonists to risk-taking and profiteering. It was the case of Captain Lafargue, in command of the French vessel the Utile, challenging the blockade imposed by the Company on slave trade in the French Mascarene islands, as he picked up his human Malagasy cargo intending to make a handsome profit by selling them on Bourbon. Some of the crew were very likely also involved in this trafficking following the new trend of pacotille (private trade conducted by sailors). The French word traite referred both to "slave trade" and "trade of various commodities".

The inaccuracy of maps - several versions were in use in the navy - including the one established by d'Après de Mannevillette, and another known as the Bayonne chart, combined with the stubbornness of the captain, drove the ship onto reefs that caused the shipwreck. The crew survived along with only half of the slaves who were trapped beneath nailed-down hatches. Many then died of thirst after landing before fresh water could be located on the island. The slaves nevertheless volunteered to build a raft (pram), while the majority of the crew spent their time hunting for birds and eggs. After the crew managed to sail away on a makeshift vessel two months later, leaving the surviving slaves behind with the promise of rescue, the slaves managed to build a raft with debris and beams and feathers for sails, and may have kept a fire burning for 15 years, though it has also been argued they used flint stones. A few women were finally rescued and taken to Bourbon. They said they had fed on fish, tortoises and birds' eggs, built shelters, and repaired utensils.

The story is known from various sources. One is a manuscript kept by the ship's writer, Hilarion Dubuisson de Keraudic, which he intended for his family, and in which he stressed the various stages of the dramatic wreck: 
The coming of day and the sight of land, which diminished our terrors, reduced none of the furies of the sea. Several people threw themselves into the water with a line to try to reach the land, to no end. A few reached the shore. We had to haul some others back over the debris, where they drowned.

We were terrified all the while because the [shattered] stern of the ship, on which we were standing, opened and closed at each moment, cutting more than one person in two. (SHD Marine, Lorient - 1P297, liasse 14, pièce 85). ${ }^{4}$

Keraudic spotted a man who was reaching for a plank and, realising he was a slave, kicked him unconscious, rescuing a wounded sailor instead. Eventually, the ship turned its stern towards the shore, allowing the sailors to establish a rope-way to the island. "All the remaining Gentlemen and crew were saved. Our losses were only 20 white men, and (two gentlemen) and many blacks, the hatches being closed or nailed down."

Some kind of discipline and hierarchy was immediately applied: one sailor sentenced for stealing was later pardoned. Space was allocated sparingly, the island being very small, i.e., less than 100 ha. The manuscript went on to indicate that almost a third of the 88 slaves originally rescued died on the next day because the sailors kept the meagre water supplies to themselves while only 20 additional Frenchmen were lost.

We made a big tent with the main sail and some flags and we (i.e. the gentlemen) lived there with all the supplies. The crew were placed in small tents. We started to feel very strongly the shortage of water. A number of blacks died, not being given any. (SHD Marine, Lorient - 1P297, liasse 14, pièce 85).

The French set up camp on the western tip of the island, while the slaves settled on the northern tip.

Order and discipline were crucial if any attempt of escape was to be made: the shipwrecks had provisions for three months. Luckily, fresh water had been found by sailors, and there was an abundant supply of fish, and birds' eggs which would provide a fairly balanced diet. The French also had numerical superiority. But Barthélémy Castellan, the first officer who had taken command after captain Lafargue had broken down, realised that he had to build a new ship very quickly if he wanted to avoid a rebellion or worse.

It seems that the ship's carpenter was useless. Castellan persuaded some slaves and crew to build the barge that would return them to Reunion Island (Bourbon Island) or Madagascar. It was reported that "The slaves toiled with great zeal" but the barge could only accommodate the 123 crew members. The slave Crusoes were left behind with the promise of rescue and letters testifying their good conduct. All but 20 out of the 100 crew played a part in constructing the barge, most preferring bird hunting, yet they were all allowed to sail away on The Providence without any of the slaves which had built the boat.

It only took four days for The Providence to reach Foulpoint in Madagascar, then Bourbon, but the local governor, Desforges-Boucher refused to send a ship to rescue the slaves citing the lack of sails and spare ships due to the war with the British, despite the pleas from the French gentlemen and sailors of the Utile and the arguments of several local dignitaries in favour of the rescue. Desforges-Boucher had other reasons to refuse. As an official of the French East India Company who had officially banned slave importation, he wanted to punish the slave-traffickers. According to Guérout, "The governor of Île de France was so angry at the late Captain La Fargue for having disobeyed his order by taking slaves aboard that he refused to send a ship to rescue the slaves." Guérout continues: "On the day the crew arrived, he (the Governor) wrote, 
'Today, the Utile survivors arrived. The captain has died. Good for him." The slaves had to pay for the captain's transgression, and rescue was not sent. But Desforges-Boucher was also most likely looking after his future profits on an illicit cargo of slaves he himself had traded; by refusing to send rescue for the slaves, he assured that there would be no competition on the market.

Determination, obstinacy and moral stamina by Castellan failed to work wonders. He almost reached the island four months later in January 1762, but the marooned slaves had to wait another 15 years, despite four rescue missions sent in 1773, 1775, and 1776. Castellan's lobbying continued in France where the castaways' ordeal had become a cause célèbre. Eventually The Dauphine, a corvette captained by Jacques-Marie Lanuguy de Tromelin, rescued seven women and a baby. The baby was christened Jacques Moyse Tsimiavo ("the one who is not proud"), his mother, Eve, and his grandmother, Dauphine.

Figure 2. Sylvain Savoia, Les Naufragés de Tromelin, Paris, Aire Libre, 2015

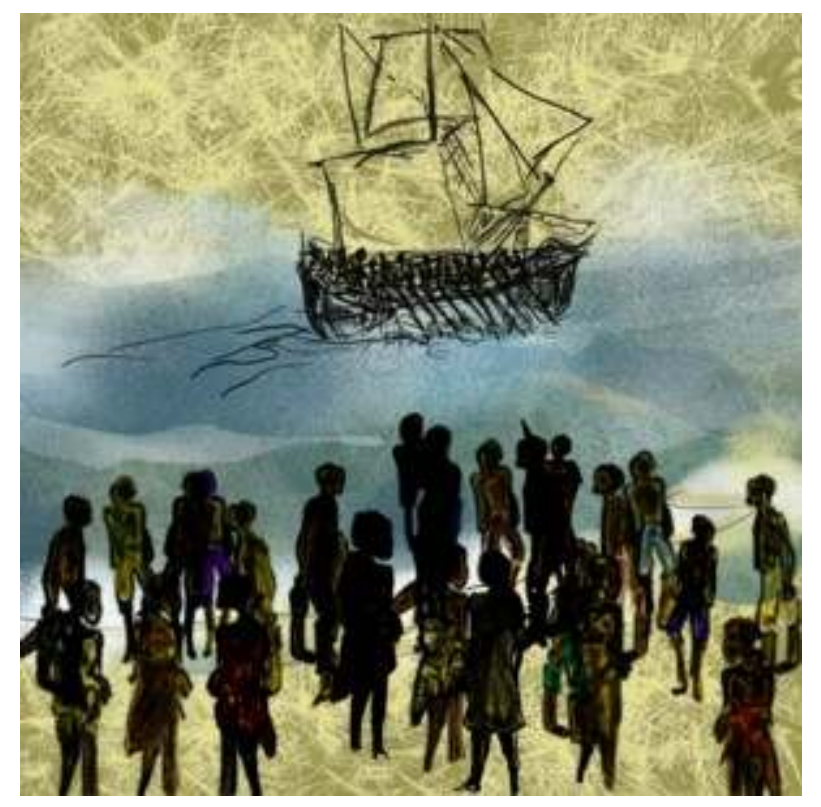

\section{Microsociety}

The details of this extraordinary ordeal of the castaways were revealed after Max Guérout, a French naval researcher whose studies focus on the archaeology of distress, published the findings of his four missions on Tromelin Island. The slaves had to survive as a community of about 60 people in the hope of the rescue they were promised. They built houses with compacted sand and blocks of coral, a meter and a half thick, to shelter themselves from the cyclones; they had a communal oven and kept a fire burning for fifteen years according to the legend although it was more likely that flint stones were used. They lived on a diet of fish, shells, birds and eggs. Several attempts to build a raft were reported, but in the absence of sails they stood little chance of reaching Madagascar or Bourbon. When a French sailor was stranded in one of the four rescue missions, he soon built a raft and then left with some volunteers for a destination they never reached (Guérout \& Romon 2010). 
he island Guérout's team unearthed stone buildings used for tombs in Madagascar but no tombs or bodies were found. The site had probably been disturbed when a weather station was put up in the 1950s. The castaways had salvaged basic implements, which they had repaired with rivets a dozen times. They had used copper for eating vessels and lead for water cisterns.

Excavations unearthed the foundations of a very well organised habitat. Out of the 400 objects found, about 50 were of real interest. They testify to the imagination and industry of the people who lived there. The inhabitants fed on birds, tortoises and their eggs. Using driftwood they protected the fire left by the sailors. Copper bowls were forged and clothes made out of bird feathers and cords. Archaeologists found shell amulets and copper bracelets made by the castaways. "These people had moved beyond the needs of survival and had set up a micro-society" explained Max Guérout. "We found sixteen spoons and sixteen copper cooking utensils." (Hopquin 2009, my translation).

The population number dropped during the first few years and then stood at about 15 , five years after the wreck and remained so over the next decade. Women, who were hardier, coped better with extreme living conditions. Did this demographic trend fit in with the resources or are there other factors? What is known is that after two years of vain hopes, eighteen people attempted to escape on a makeshift raft. For the rest, we can assume they died of despair, diseases or intestine fights. Did they fight for survival or was solidarity the key? The expedition searched a graveyard spotted by a British navigator in 1851. Bones, broken skulls would give us precious details (Guérout \& Romon 2010, my translation). ${ }^{5}$

For Guérout, the Tromelin Island castaways were true survivors:

These were not people who were overwhelmed by their fate. They were people who worked together successfully in an orderly manner. We have found evidence of where they lived and what they ate. We have found copper cooking utensils, repaired over and over again, which must have originally come from the ship. It's a very human story, a story of instinct and survival of people who were abandoned because they were regarded by some of their fellow human beings as less human (Guérout \& Romon 2010).

\section{A Crime of Lese-Humanity}

That the story of the slaves has survived is largely due to a central figure of the French Revolution, the Marquis de Condorcet, and his 1781 pamphlet Reflections on Negro Slavery. Yet this awareness did not come to the Navy officers or to the East India Company officials too concerned with the protection of their own slave trade, hence the stern refusal of Desforges-Boucher, then Bourbon's governor, to save the shipwrecked slaves. When they were finally rescued in 1776 , this wake-up call spread to Ile de France, then to philosophical circles, Masonic lodges and learned salons. The story of the castaways was included by Condorcet in his Reflexions on Negro Slavery: De l'Esclavage des Noirs, which then lead to the decree on the abolition of slavery passed on February 4, 1794 by the Convention, according to which all men without any distinction of color, living in the colonies as French citizens, enjoyed all the rights guaranteed by the Constitution (Hunt 1996: 55-57). ${ }^{6}$ Slavery would be reinstated shortly afterwards under Napoleon in 1802, before being finally unconditionally abolished in 1848 .

In the late eighteenth-century, the Tromelin Island tragedy was further reported in literary circles by Bernardin de Saint-Pierre, Abbé Pingré, Abbé Rochon, published in gazettes and newspapers in Liege and Geneva, and the tale was also circulated by peddlers across Europe.

Angles, 9 | 2019 


\section{Conclusion}

\section{Realpolitics: Tromelin's Status in the $21^{\text {st }}$ Century}

Claimed by Mauritius and Madagascar, the island has remained a French territory. Novelist Irène Frain, called upon to give her opinion to a parliamentary committee in the light of the slave tragedy 250 years ago, reminded the committee that France had displayed throughout the centuries its interest for this island, asserting its presence there. As of late, other countries have also expressed interest because of the wealth included in the $240,000 \mathrm{~km}^{2}$ of exclusive economic zone around Tromelin, two-thirds the size of France's own economic zone. Yet France had a duty to be the watchman in this area. Frain stressed that pirates attempted to take possession of the island a few years ago. Tromelin stands as a bulwark against pirates who could operate from there if it were abandoned by France. The same can be said of the Scattered Islands. Far from being "the Empire's confetti", Tromelin is strategically important for France (Frain 2015).

Philippe Foliot, a French Member of Parliament, indicated that the refusal of the French Parliament to vet the treaty of co-management of Tromelin with Mauritius was a unique example in the history of the Fifth Republic. The dispute goes back to the Versailles Treaty in 1815 by which France handed Mauritius and other islands over to Britain, but Tromelin is not mentioned as such in the Treaty. Historically and legally, Mauritius cannot claim any rights on Tromelin and has not started any formal proceedings before the International Court of Justice. An agreement handing the island over to Mauritius could be unjust and dangerous. It could have a domino effect on other French islands in the area: Scattered Islands, claimed by Madagascar, and Juan de Nova (also known as Saint-Christophe), claimed by Mozambique.

\section{Afterword: A “lieu de mémoire”}

Memorialisation of slavery is still a major concern in some parts of the world, notably in Africa and Europe. The little-known tragedy of the slaves of Tromelin Island inspired Irène Frain and was the theme of an exhibition in the Musée de l'Homme in Paris in 2019. Yet beyond such literary tracks, a more enduring legacy is needed, and some charities could start a campaign to honour the men and women who triggered Western awareness and helped put an end to human trafficking. The idea of a monument erected on the island is worth considering. It could be named Tsimiavo - the one who is not proud - after the name of the last baby born on Tromelin. 
Figure 3. An aerial view of Tromelin Island

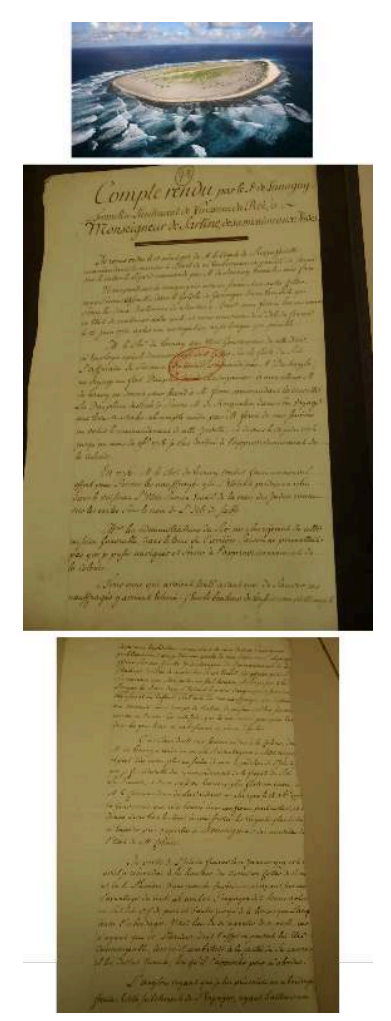

Source: AFP

\section{BIBLIOGRAPHY}

Archives, Compte rendu par le Sr de Lanuguy Tromelin, lieutenant de vaisseau du roi à Monsieur de Sartine de sa mission aux Indes, Ms 161/90, Service historique de la défense, Brest.

Boateng, Osei. “Just an ‘Appalling Tragedy’” New African 398 (July/August 2001): 24-29.

Campbell, Gwyn. The Structure of Slavery in Indian Ocean Africa and Asia. London: Frank Cass, 2004.

Frain, Irene. “Compte rendu de l'audition de Mme Irène Frain, écrivain et auteur de « Les naufragés de l'île Tromelin » à l'Assemblée Nationale par Christophe Premat. Député suppléant des Français établis en Europe du Nord (XIV ème législature)." 17 March 2015. https:// christophepremat.com/2015/03/17/compte-rendu-de-laudition-de-mme-irene-frain-alassemblee-nationale-ecrivain-et-auteur-de-les-naufrages-de-lile-tromelin-2/

Frain, Irene. Les Naufragés de l'île Tromelin. Paris: Michel Laffont, 2009.

Groupe de Recherche en Archéologie Navale (GRAN), http://archeonavale.org/gran2012/

Grove, Richard. Green Imperialism: Colonial Expansion, Tropical Island Edens and the Origins of Environmentalism, 1600-1860. Cambridge: Cambridge UP, 1995. 
Guérout, Max et Thomas Romon. Tromelin - L'île aux esclaves oubliés. Paris: CNRS Éditions, INRAP, 2010.

Guérout, Max. Tromelin, Mémoire d'une île. Paris: CNRS Editions, 2015

Gupta, Pamila. Island-ness in the Indian Ocean.Pretoria: Unisa Press, 2010.

Hopquin, Benoit. “Archéologie : sur les traces des Robinson noirs.” In Le Monde 2 May 2009.

http://www.lemonde.fr/planete/article/2009/04/30/archeologie-sur-les-traces-des-robinsonnoirs_1187426_3244.html

Hunt, Lynn (ed. \& trans.). “A Brief Documentary History, Marie Jean de Caritat, Reflections on Negro Slavery.” In The French Revolution and Human Rights. Boston: Bedford, 1996. 55-57.

Le Lan, Jean-Yves. “Le Naufrage de l’Utile.” Histoire Généalogie. March 12, 2009. https:// www.histoire-genealogie.com/Le-Naufrage-de-l-Utile?lang=fr

“Lèse humanité: An 18th-century outrage." The Economist, 16 Dec. 2016. https:// www.economist.com/christmas-specials/2015/12/16/lese-humanite?fsrc=scn/tw/te/rfd/pe? $\mathrm{fsrc}=\mathrm{scn} / \mathrm{fb} / \mathrm{te} / \mathrm{pe} / \mathrm{ed} /$ lsehumanit

Lichfield, John. "Shipwrecked and Abandoned: The Story of the Slave Crusoes." The Independent. February 5, 2007. https://www.independent.co.uk/news/world/africa/shipwrecked-andabandoned-the-story-of-the-slave-crusoes-435092.html

Peabody, Sue. "Race, Slavery, and the Law in Early Modern France.” The Historian 57.4 (1994): 501-510. DOI: 10.1111/j.1540-6563.1994.tb01322.x

“Piracy: Special Edition." Standard Bulletin. September 2011. https://www.standard-club.com/ media/1557914/introduction-to-standard-bulletin-piracy-special-edition-september-2011.pdf Richardson, David. Abolition and its Aftermath: The Historical Context 1790-1916. London: Routledge, 1988.

Savoia, Syvain. Les Esclaves Oubliés de Tromelin. Paris : Aire Libre, 2015.

"Shipwrecked and abandoned: the story of the slave Crusoes." The Independent, 5 February 2007. https://www.independent.co.uk/news/world/africa/shipwrecked-and-abandoned-the-story-ofthe-slave-crusoes-435092.html

Sopova, Jasmina. "The Shipwrecked Memory of the Slaves." In The New Courier. UNESCO. May 2005. https://unesdoc.unesco.org/ark:/48223/pf0000139495

Sutter, John D. “Slavery's Last Stronghold.” CNN. 2014. https://edition.cnn.com/interactive/ 2012/03/world/mauritania.slaverys.last.stronghold/index.html

The History of Rodrigues. http://iocp.potomitan.info/rodrigues/rodrigues.htm

The Indian Ocean and East African Slave Trade: Ethiopia. http://histclo.com/act/work/slave/ast/ io/cou/sc-eth.html

Thomas, Hugh. The Slave Trade: The Story of the Atlantic Slave Trade 1440-1870. New York: Simon \&Schuster, 1997.

“Tromelin.” BirdLife International Important Bird Areas (IBAs) Fact Sheet. Birdlife.org. 2004. http://datazone.birdlife.org/site/factsheet/tromelin-iba-french-southern-territories Weiss, Gillian. Captives and Corsairs: France and Slavery in the Early Modern Mediterranean. Palo Alto: Stanford UP, 2011. 


\section{APPENDIXES}

Marie Jean de Caritat, Marquis de Condorcet (1743-94) published Réflexions sur l'esclavage des nègres, a powerful pamphlet attacking slavery written under the pseudonym of Mr. Schwartz, pastor at Bienne, in Neufchatel (Switzerland) in 1781. Condorcet described the slave system as a crime and demanded its abolition. $\mathrm{He}$ associated the abolition of slavery with other reforms such as civil rights for Protestants, the elimination of the last vestiges of serfdom and the rights of women. In 1788, Condorcet helped found a French Society of the Friends of the Blacks based on earlier groups. Affiliated with the Girondins, he was arrested during the Terror for opposing the growing power of the state and died in jail.

Figure 4. Réflexions sur l'esclavage des nègres par M. Schwartz (Reflections on the Enslavement Negroes by M. Schwartz)

\section{RÉFLEXIONS} $S \cup R$

L'E S C L A V A G E DES NEGRES. PAR M. SCHWARTZ, Pafteur du Saint-Evangile à Bienne, Membre de la Societt economigue de $B^{* * * *}$.

A N EFCHA T E Chez la Sociéte TYPOGRAPHI

M. D C C. L.X X X I.

\begin{tabular}{|l|l|}
\hline Épître dédicatoire aux nègres esclaves & A dedicatory letter to the Negro slaves \\
\hline Mes amis, & My Friends, \\
\hline
\end{tabular}


Quoique que je ne sois pas de la même couleur que vous, je vous ai toujours regardé comme mes frères. La nature vous a formés pour avoir le même esprit, la même raison, les mêmes vertus que les Blancs. Je ne parle ici que de ceux d'Europe, car pour les Blancs des Colonies, je ne vous fais pas l'injure de les comparer avec vous, je sais combien de fois votre fidélité, votre probité, votre courage ont fait rougir vos maîtres. Si on alloit chercher un homme dans les Isles de l'Amérique, ce ne seroit point parmi les gens de chair blanche qu'on le trouveroit.

Votre suffrage ne procure point de places dans les colonies, votre protection ne fait point obtenir de pensions, vous n'avez pas de quoi soudoyer les avocats; il n'est donc pas étonnant que vos maîtres trouvent plus de gens qui se déshonorent en défendant leur cause, que vous n'en avez trouvés qui se soient honorés en défendant la vôtre. Il y a même des pays où ceux qui voudroient écrire en votre faveur n'en auroient point la liberté. Tous ceux qui se sont enrichis dans les Isles aux dépens de vos travaux \& de vos souffrances, ont, à leur retour, le droit de vous insulter dans des libelles calomnieux; mais il n'est point permis de leur répondre. Telle est l'idée que vos maîtres ont de la bonté de leur droit; telle est la conscience qu'ils ont de leur humanité à votre égard.

Mais cette injustice n'a été pour moi qu'une raison de plus pour prendre, dans un pays libre, la défense de la liberté des hommes. Je sais que vous ne connoîtrez jamais cet Ouvrage, \& que la douceur d'être béni par vous me sera toujours refusée. Mais j'aurai satisfait mon cœur déchiré par le spectacle de vos maux, soulevé par l'insolence absurde des sophismes de vos tyrans. Je n'emploierai point l'éloquence, mais la raison, je parlerai, non des intérêts du commerce, mais des loix de la justice.

Vos tyrans me reprocheront de ne dire que des choses communes, \& de n'avoir que des idées chimériques ; en effet, rien n'est plus commun que les maximes de l'humanité \& de la justice; rien n'est plus chimérique que de proposer aux hommes d'y conformer leur conduite.
Although I am not of the same color as you, I have always regarded you as my brothers. Nature has formed you to have the same spirit, the same reason, the same virtues as Whites. I speak here only of those in Europe, as for Whites of the Colonies, I do not insult you to compare them with you; I know how many times your loyalty, your honesty, your courage have left your masters ashamed. If we were looking for man in the Caribbean, the point would not be to search among the white people.

You have no right to vote in the colonies, you get no pensions, you have nothing to bribe the lawyers with so it is not surprising that your masters dishonor themselves by defending their cause rather than find honor by defending yours. There are even countries where those who would write in your favor are not free to. All those who got rich in the colonies at the expense of your work and your sufferings have, in turn, the right to insult you with scurrilous libels, and it is not possible to answer them. This is the idea that your masters have of the propriety of their right, such is their awareness of your shared humanity.

But this injustice has been the only for me a reason to take on, in a free country, the freedom of men. I know you will never know of this work, and that I will always be denied the pleasure of being blessed by you. But I my heart is torn by the spectacle of your ills, and worsened by the insolence of the absurd fallacies of your tyrants. I will not employ the point eloquently, but the reason I will speak, not the interests of trade, but the laws of justice.

Your tyrants reproach me for saying the obvious, and for fanciful thinking; in fact, nothing is more common than the maxims of humanity \& justice, nothing is more fanciful than to suggest that men conform. 
Préface des éditeurs

M. SCHWARTZ

nous ayant envoyé son manuscrit, nous l'avons communiqué à $\mathrm{M}$. le Pasteur $\mathrm{B}^{* * * * * * *}$, l'un de nos associés, qui nous a répondu que cet Ouvrage ne contenoit que des choses communes, écrites d'un style peu correct, froid et sans élévation ; qu'on ne le vendroit pas, et qu'il ne convertiroit personne.

Nous avons fait part de ces observations à $M$. SCHWARTZ, qui nous a honorés de la lettre suivante.

« Messieurs,

Editors' Preface

Je ne suis ni un bel esprit Parisien, qui prétend à l'académie françoise, ni un politique Anglois, qui fait des pamphlets, dans l'espérance d'être élu membre de la chambre des Communes, \& de se faire acheter, par la Cour, à la première révolution du ministere. Je ne suis qu'un bon homme, qui aime à dire franchement son avis à l'univers, \& qui trouve fort bon que l'univers ne l'écoute pas. Je sais bien que je ne dis rien de neuf pour les gens éclairés, mais il n'en est pas moins vrai que, si les vérités qui se trouvent dans mon Ouvrage étoient si triviales pour le commun des François ou des Anglois, \&c. l'esclavage des Negres ne pourroit subsiter.

"Messieurs,

I am neither a Parisian with claims to the French academy, nor an English politician, who writes pamphlets hoping to be elected to the House of Commons, and be bought by the Court at the first revolution of the Ministry. I am a good man, who likes to speak his opinion frankly to the world, so it is very good that the universe does not listen. I know I say nothing new to enlighten readers, but it is nonetheless true that if the truths found in my work were so trivial for the average of the French or English, \& c. Negro slavery might persist.

Il est très-possible cependant que ces réflexions ne soient pas plus utiles au genre humain que les Sermons que je prêche depuis vingt ans, ne sont utiles à ma paroisse, j'en conviens, \& cela ne m'empêchera pas de prêcher \& d'écrire tant qu'il me restera une goutte d'encre \& un filet de voix. Je ne prétends point d'ailleurs vous vendre mon manuscrit. Je n'ai besoin de rien, je restitue même à mes paroissiens les appointemens de Ministre que l'État me paye. On dit que c'est aussi l'usage que font de leur revenu tous les Archevêques \& Évêques du clergé de France, depuis l'année 1750 , où ils ont déclaré solemnellement à la face de l'Europe, que leur bien étoit le bien des pauvres.

It is quite possible, however, that these reflections are no more useful to mankind than the sermons I preached for twenty years in my parish, but that will not stop me from preaching or writing as long as I have a drop of ink or a thin voice. Nor do I pretend that you will be able to sell my manuscript.

I do not need anything, I even send my parishioners the Minister's salary that the State pays me. They also say that, since 1750 , the use to which all of the Archbishops \& Bishops in France put their income, as they solemnly declare across Europe, was good for the poor.

J'ai l'honneur d'être avec respect, \&c.

Signé Joachim SCHWARTZ, avec paraphe. »

Cette lettre nous a paru d'un si bon homme, que nous avons pris le parti d'imprimer son ouvrage. Nous en Honored by the respect I pay, \& c.

serons pour nos frais typographiques, ou les lecteurs pour quelques heures d'ennui. 


\section{NOTES}

1. With the support of the Academie des Sciences, d'Après de Mannevillette published in Paris in 1745 a number of charts for a hydrographic atlas under the title "Le Neptune Oriental" which featured 25 maps. For the following three decades, with the help of his friend and eminent British hydrographer Alexander Dalrymple, Mannevillette revised his charts for a second enlarged edition. This comprehensive atlas was used on all French and by some foreign ships navigating the Indian Ocean. It replaced the "English Pilot" published by John Thornton in 1700 and the charts of the van Keulens, the hydrographers of the Dutch East India Company. See https://www.swaen.com/neptune-oriental.php/

2. The French entered the stage in 1691 with the most famous of the early inhabitants, Francois Leguat and his small band of Protestant refugees. Many Huguenots were escaping from Catholic France under persecution from Louis XIV. Henri Duquesne, the son of a famous Admiral had a plan to establish a republic of Protestant refugee on a distant island. He publicised his campaign and called his proposed colony Eden. After having spent a fortune on the scheme, Duquesne and most of his fleet had to stay behind to fight against the Dutch. Only eight colonists sailed on L'Hirondelle with instructions to take possession of Rodrigues and wait for an opportunity to colonize Reunion. Leguat and seven young companions spent over two years on Rodrigues, living on the left bank of the river running to the east of Port Mathurin. They spent their time cultivating their gardens, building huts, fishing and playing chess. They did not have much success with their own crops, but there was an abundance of tortoises, turtles, birds, fish and other sea food. Within 50 years, the entire population of 200,000 tortoises had been wiped out and removed. The last reference of tortoises seen alive was by Marragon in 1795 where he had come across a few in the most inaccessible ravines. Leguat was a keen observer of nature and as an older man was very happy with the life on Rodrigues. Using wood from a shipwreck and tortoise oil as caulking, they built a six metre boat to make the voyage to Mauritius. However, it was to be three long years before they would find the company of women. Mauritius was occupied by the Dutch, and as they were still at war with France the unlucky colonists were imprisoned as spies for two and a half more years. By this time, two had drowned and one had died of dysentery. The remaining group had to serve a further year in the army before returning home to Flushing in 1698. Leguat's book became a bestseller, but some of his stories were dismissed as fantasy. http://iocp.potomitan.info/rodrigues/rodrigues.htm, Accessed June 29, 2019.

3. "The French East India Company for decades was content to produce provisions only for its own needs and those of any passing ships. This changed when coffee was introduced (1715). Coffee quickly became the island's principal cash crop which fundamentally changed the economy. The French enslaved more Africans to carry out the intensive labour required for growing and harvesting coffee. The French also introduced other cash crops (cereal grains, spices and cotton)." The Indian Ocean and East African Slave Trade: Ethiopia. http://histclo.com/act/ work/slave/ast/io/cou/sc-eth.html.

4. "Le Jour Et la Vüe de la terre qui avoient un Peu Diminuer nos frayeurs n'avoient rien otér à la mer de Ses Fureurs, Plusieurs Personnes Se Jetterent à la mer avec Une Ligne pour Tacher de gagner La Terre Et Etablir Un Va-Et-Vient Inutillement, quelqu'uns gagnerent Sans Pouvoir rien Porter, Il falloit haller les autres Sur Les Debris, où Ils Se Seroient Noyez, Enfin Effrayé de ce que Le derriere Sur le Costé duquel nous Etions Souvroit Et fermoit a chaque Instant qui à coupé en deux Plusieurs".

5. Benoit Hopquin, Le Monde, 2 May 2009. http://www.lemonde.fr/planete/article/2009/04/30/ archeologie-sur-les-traces-des-robinson-noirs_1187426_3244.html

6. Marie Jean de Caritat, Marquis de Condorcet (1743-94) published a powerful pamphlet attacking slavery in 1781, under a pseudonym. This nobleman described the slave system as a 
crime and demanded its abolition. He associated the abolition of slavery with other reforms like civil rights for Protestants, the elimination of the last vestiges of serfdom and the rights of women. In 1788, Condorcet helped to found a French Society of the Friends of the Blacks based on earlier groups. Affiliated with the Girondins, he was executed during the Terror for opposing the growing power of the state: Marie Jean de Caritat, "Reflections on Negro Slavery," in The French Revolution and Human Rights: A Brief Documentary History, ed. and trans. by Lynn Hunt (Boston: Bedford, 1996), 55-57.

\section{ABSTRACTS}

The account of the shipwreck of the French East India Company vessel, the Utile, in 1761 and the ordeal of the marooned slaves provide a specific perspective on the economics, geopolitics, science, ideology and ethics prevailing in the late 18th century. The background to the tragedy of the marooned slaves underlines the role and status of the ports of calls European trading companies occupied to ensure their safe passage to India, ranging from basic havens to settlements or factories. Their economic role on the trade routes was vital as a source of food and water crews needed to get fresh supplies and cure their sick. They were also politically essential and constituted a source of rivalry between the Dutch, Portuguese, English, and French. Ideologically, they reflected the relation with local populations and exploitation of natural resources - the demise of the dodo on Mauritius being a case in point, as well as the transplantation of precious spices to Mauritius by the French naturalist Poivre from the wellprotected Dutch factories in Indonesia. Utopian schemes were sometimes enacted on these tiny islands picked randomly or used as safe havens after shipwrecks or again selected as spaces where societies would be born anew for new pilgrims and outcasts. A large body of literature, be it travel accounts, logbooks or fiction, emerged on those topics both in France and Britain foregrounding revolutionary ideas in 18th century Europe.

Le récit du naufrage en 1761 de L'Utile, vaisseau de la Compagnie Française des Indes Orientales, et l'épreuve des esclaves naufragés présentent une grille de lecture sur l'économie, la géopolitique, la science, l'idéologie dominante en cette fin du XVIII ${ }^{\mathrm{e}}$ siècle. Cet article inscrit la tragédie dans le contexte des ports d'escale que les compagnies de commerce européennes avaient occupé pour assurer la sécurité de leurs voyages vers l'Inde, qu'il s'agisse de havres naturels, d'établissements commerciaux ou de simples comptoirs. Leur rôle économique sur les routes commerciales était vital car les équipages des navires avaient besoin de nourriture et d'eau et devaient soigner leurs malades. Politiquement, ils étaient également indispensables et source de rivalité entre les Hollandais, les Portugais, les Anglais et les Français. Idéologiquement, ils reflètent la relation avec les populations locales et l'exploitation des ressources naturelles, la disparition du dodo sur l'Ile Maurice étant un cas d'école ainsi que la transplantation par le naturaliste français Poivre sur cette même île d'épices précieuses prélevées dans les comptoirs hollandais jalousement protégées en Indonésie. Des schémas utopiques ont parfois été mis en œuvre sur ces petites îles choisies au hasard ou identifiées comme refuges après les naufrages, ou encore sélectionnées comme des espaces où les sociétés renaîtraient pour abriter des nouveaux pèlerins et des exclus. Une littérature abondante, qu'il s'agisse de journaux de voyage, de journaux de bord, ou de récits fictionnels, a émergé sur ces sujets, en France et en GrandeBretagne, annonçant des idées révolutionnaires de l'Europe du XVIII ${ }^{\mathrm{e}}$ siècle. 
INDEX

Keywords: Tromelin Island, utopia, dystopia, spice trade, slavery, Condorcet, Anglo-French rivalry, 18th century

Mots-clés: Île Tromelin, utopie, dystopie, commerce des épices, esclavage, Condorcet, rivalité anglo-française, XVIIIe siècle

\section{AUTHOR}

\section{JOËLLE WEEKS}

Joëlle Weeks is Honorary Associate Professor of English at Université Paris I - Panthéon Sorbonne. She is the author of Représentations européennes de l'Inde du XVIIe au XIXe siècle (Harmattan, 2010), and has co-edited La terre, Question vitale au XXIe siècle (Harmattan, 2012). Contact: joelle.weeks[at]univ-paris1.fr 